\title{
KONTROVERSI JFC (JEMBER FASHION CARNAVAL) KE-18 DALAM DISKURSUS MEDIA DAN PEMIKIRAN TOKOH AGAMA DI JEMBER
}

\author{
BUNGA SURAWIJAYA NINGSIH \\ Komunikasi dan Penyiaran Islam Pascasarjana IAIN Jember \\ intanbelliana30@gmail.com
}

Diunggah 10 September / Direvisi 10 Oktober / Diterima 10 November 2020

\begin{abstract}
Abstrac: The 18th JFC (Jember Fashion Carnaval) in 2019 chose Cinta Laura Kiehl as its grand ambassador. The event, which is held in every year never escapes from the media spotlight. One of them happened in 2019. this event made by Dynand Fariz which is caused controversy among public and the mass media. This event invited polemics to the response of MUI Jember,the management of Muhammadiyah Jember, and the chief of FPI East Java since the clothes that is worn by cinta laura. this phenomenon, such as in media Bangsaonline.com and Potrerjember.com which are East Java media and online media that contain the most news about the 18th JFC controversy in 2019. In this study, researchers used William A. Gamson's framing analysis method and Andre Modiglani, which emphasized to the symbolic form through figurative and rhetoric which indirectly directs the news which forms an image from certain aspects in the public. In addition, it also contains of the views of religious leaders in Jember. The result was that Bangsaonline.com andotretjember.com looked shy when it reportes the controversy news. However, in the packaging of the news, words, terms, phrases, sentences, facts, paragraphs, and images used by online media tend to highlight images that indulge in genitals and violate religious values.
\end{abstract}

Keywords: Controversy, JFC (Jember Fashion Carnaval), Framing Analysis.

Korespondensi: Bunga Surawijaya Ningsih

IAIN Jember

intanbelliana30@gmail.com 


\section{A. PENDAHULUAN}

Wawasan kebangsaan tidak terlepas dari kebudayaan yang berakar dari nilainilai budaya dalam menyampaikan makna identitas kepribadian dirinya yang berbeda-beda dengan orang lain. Melalui simbol, manusia secara alamiah menunjukkan ide, gagasan dan konsep pemikirannya yang kemudian diwujudkan dalam berbagai hal, khususnya berupa nilai-nilai yang terlihat. Nilai-nilai tersebut dapat diaplikasikasn melalui tingkah laku, sikap, kreatifitas manusia sebagai wujud dari identitasnya. Oleh karena itu untuk membangun identitas dibutuhkan media efektif dan partisipatif yang mampu menangkap nilai-nilai moral masyarakat.

Jember Fashion Carnival (JFC) merupakan salah satu contoh karnaval pada orde baru. JFC dipilih sebagai media untuk membangun wawasan kebangsaan yang berakar pada budaya nasional. Jember yang mempunyai latar belakang masyarakat pandalungan, diantaranya masyarakatnya terbentuk sebuah karnaval fashion yang saat ini dikenakan hingga dunia. Fenomena ini menjadi hal yang menarik, karena Jember tidak mempunyai riwayat sejarah fashion dan dikenal dengan kota santri. JFC yang diprakarsai oleh Dynand Fariz telah menunjukkan eksistensinya selama 18 tahun dan telah berhasil merubah jember menjadi kota karnaval tingkat dunia.

Cinta Laura Kiehl yang merupakan grand ambassador dari acara JFC ke-18 tahun 2019 juga tidak luput dari sorotan media. Busana yang dikenakan oleh artis ibukota ini mengundang polemik hingga memuai tanggapan dari ketua MUI Jember, Prof.Abdul Halim Subahar. Gus Halim panggilan akrabnya, menyorot kostum yang dikenakan Cinta Laura karena dinilai mengumbar aurat. Artis ibukota ini dinilai terlalu vulgar dan berani saat berada di Jember, yang notabene mendapat predikat sebagai kota santri. Pengurus Daerah (PD) Muhammadiyah Jember, Kusno juga ikut menanggapi gelaran JFC, terutama penampilan seksi artis ibu kota. Ketua PD Muhammaddiyah Jember ini menyayangkan tampilan JFC yang dinilai kurang mengangkat kearifan lokal dan kurang menghargai nilai-nilai dari kota santri. Meskipun tema utama yang diusung mengenai ragam budaya bangsa sejagat. Habib Haidar Alhamid yang merupakan Ketua Front Pembela Islam (FPI) Jawa timur juga ikut angkat suara. Menurutnya pagelaran JFC ini melanggar norma-norma kesusilaan dan agama, sehingga FPI menolak keras acara JFC.

Dalam pemberitaan media massa terdapat tujuan untuk meraih simpati dari masyarakat untuk memberikan dukungan atau hak suaranya atas peristiwa yang 
dikemas. Media massa merupakan agen konstruksi, artinya pembentukan suatu berita dalam media massa di dasarkan pada penyusunan realita terhadap suatu peristiwa, sehingga memuat berita atau wacana yang bermakna. ${ }^{1}$

Kontroversi JFC ke-18 pada saat ini, menjadi perbincangan yang hangat ditengah-tengah masyarakat yang dikonstruksikan oleh media. Pro kontra atas kontroversi ini menjadi perdebatan wacana diruang publik. Bangsaonline.com dan potretjember.com merupakan media online yang dipilih. H.M. Mas'ud Adnan yang merupakan pimpinanan dari bangsaonline.com dan media ini sudah mendirikan media online sejak tahun 2014. Bangsaonline.com dan potretjember.com dipilih karena media ini merupakan media Jawa Timur dan media online yang paling banyak memuat pemberitaan tentang kontroversi JFC ke-18 tahun 2019.

Urgensi dari penelitian ini adalah karena peneliti melihat beberapa hal yang layak dijadikan pertimbangan; pertama, karena acara JFC ini merupakan acara yang setiap satu tahun sekali digelar dan baru menimbulkan kontriversi pada pagelaran JFC yang ke-18. Kedua, pagelaran JFC ini yang awalnya berkeinginan menjadikan kota Jember sebagai kota wisata mode pertama di Indonesia dengan memperkenalkan kostum budaya kota Jember yang notebennya merupakan kota santri akan tetapi kebudayaan itu tidak tertampilkan dalam pagelaran ini. Kedua pertimbangan di atas tidak luput dari peran media khususnya media online.

Dalam menganalisa penelitian tersebut, peneliti memilih metode analisis framing William A. Gamson dan Andre Modoglani. Dipilihnya model ini dengan pertimbangan bahwa William A. Gamson dan Andre Modoglani menekankan pada penandaan dalam bentuk simbolik, baik lewat kiasan maupun retorika yang secara tidak langsung mengarahkan berita sehingga membentuk citra pada aspek tertentu kepada khalayak. Perangkat dalam metode ini dapat membantu peneliti untuk melihat bahasa secara mikro, terutama dalam menganalisis kalimat yang menonjolkan istilah-istilah yang menuju pada penggambaran citra tertentu, dan didukung dengan foto atau gambar.

Penelitian dengan metode analisis framing bertitik tolak dari asumsi bahwa media dapat mengkonstruksi realitas. June Woong Rhe mengatakan bahwa media membingkai kejadian dengan cara yang dapat membatasi bagaimana khalayak

1 Eriyanto,Analisis Framing (Konstruksi, Ideologi dan Politik Media,(Yogyakarta:PT.LKiS Printing Cemerlang.2002),25. 
menafsirkan kejadian tersebut. Hal ini dapat terjadi dengan berbagai fitur tekstual dari "cerita", seperti berita utama, komponen audio visual, metafora yang digunakan, dan cara pencitraan, untuk menyebutkan beberapa cara frame bekerja. ${ }^{2}$

Secara sederhana analisis framing dapat digambarkan sebagai analisis untuk mengetahui bagaimana realitas dibingkai oleh media. Pembingkaian ini melalui proses konstruksi. Realitas dimaknai dan dikonstruksi dengan makna tertentu. Peristiwa dipahami dengan bentukan tertentu. Hasilnya, pemberitaan media pada sisi tertentu atau wawancara dengan orang-orang tertentu. ${ }^{3}$

\section{B. PEMBAHASAN}

\section{Ideologi dan Kepentingan Media}

Ideologi adalah salah satu faktor yang mempengaruhi penyajian berita. Baik bagaimana media masa berperan serta dalam mempropagandakan ideologi atau mempropagandakan kekuatan yang menentukan sifat ideologi tersebut.

Matthew Kieran menegaskan bahwa berita tidaklah dibentuk dalam ruang hampa. Berita diproduksi dari ideologi dominan dalam suatu wilayah kompetensi tertentu. ${ }^{4}$ Tidak dapat dipungkiri bahwa saat ini berita kian banyak diproduksi oleh perusahaan-perusahaan non-jurnalisme. Bahkan Bill Kovach dan Tom Rosenstiel dalam bukunya "Sembilan Elemen Jurnalisme" mengindikasikan bahwa berita yang independen akan tergantikan oleh komersialisme untuk kepentingandiri sendiri yang menyaru sebagai berita. ${ }^{5}$

Daniel Hallin membuat ilustrasi dan gambaran menarik yang menolong menjelaskan bagaimana berita ditempatkan dalam bidang atau peta ideologi.

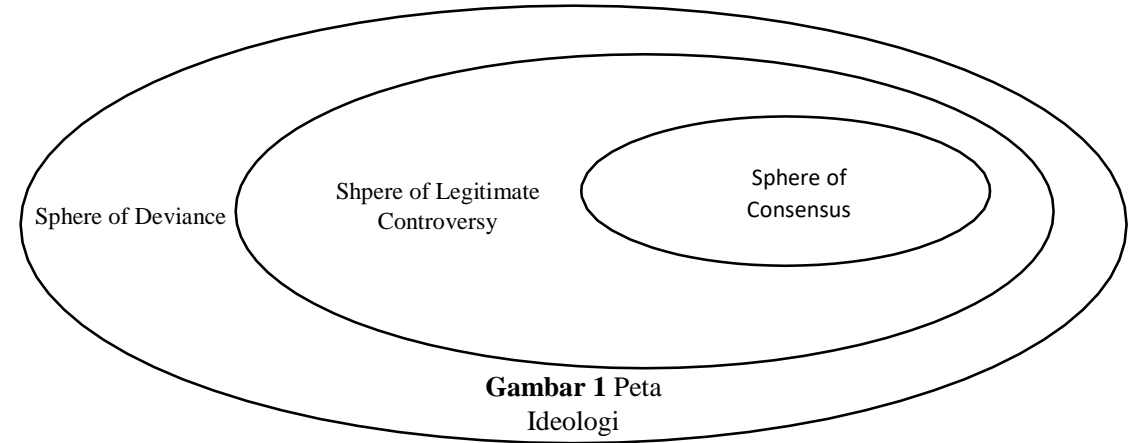

2 Stephen W. Littlejhon dan Karen A. Foss, Theoris of Human Communication. Ninth Edition.Belmont(California:Wadsworth Publishing Company,2008),294.

3 Eriyanto, Analisis Framing. Cetakan V....,3.

${ }^{4}$ Eriyanto,Analisis Framing.Cetakan V...,130.

${ }^{5}$ Bill Kovach dan Tom Rosenstiel,Sembilan Elemen Jurnalisme,Terjemahan,(Jakarta:Pantau,2003),91. 
Hallin membagi dunia jurnalistik ke dalam tiga bidang, yaitu : Bidang penyimpangan (sphere of deviance), bidang kontroversi (sphere of legitimate controversy), dan bidang consensus (sphere of consensus. Bidang-bidang ini menjelaskan bagaimana peristiwa-peristiwa dipahami dan ditempatkan oleh komunikator dalam keseluruhan peta ideologis. Dalam wilayah ini suatu peristiwa, gagasan atau perilaku tertentu dikucilkan dan dipandang menyimpang. Sedangkan wilayah kontroversi menitikberatkan pada sebuah realitas yang masih diperdebatkan atau dipandang kontroversional. Sementara wilayah yang dianggap paling dalam ialah consensus. Pada wilayah ini menunjukkan bagaimana realitas tertentu dipahami dan disepakati secara bersam-sama sebagai realitas yang sesuai dengan nilai-nilai ideologi kelompok. ${ }^{6}$

Pertanyaannya ialah bagaimana ideologi bias kita lihat dalam teks? Kita bisa melihat dari bagaimana politik penandaan dilakukan oleh media. Bagaimana dari sisi-sisi yang ada, media menempatkan dirinya. Melalui peta (mapping), peristiwa-peristiwa yang dibuat bermakna dalam wacana berita.

Kaitannya dengan kepentingan media, Tom Johnson, Presiden Cable News Network yang juga mantan penerbit Los Angeles Times, sampai pada kesimpulan bahwa para pemilik atau dalam kasus perusahaan yang sudah masuk bursa saham, CEO yang dipilih dewan komisaris, akhirnya yang memutuskan kualitas berita yang dihasilkan oleh televise atau bagian dari pemberitaan mereka. Merekalah yang paling sering memilih, memperkerjakan, memecat, mengankat para redaktur, pimpinan umum, general manager puncak, direktur pemberitaan sampai dengan redaktur pelaksaan. Mereka semua menetapkan standart mutu berdasarkan kualitas orang yang mereka pilih dan kebijakan berita yang mereka pegang. Pemilik menetukan berapa banyak keuntungan yang bias mereka hasilkan dari kepemilikan media. Pemilik menentukan jenjang kualitas yang sudah mereka dukung berdasarkan seberapa baik atau seberapa buruk mereka membayar komunikator mereka. $^{7}$

Dari uraian di atas, menurut Ibnu Hamad mengatakan jika melalui yang dibuatnya, media melakukan pembelaan yang kuat terhadap sebuah kekuatan politik maka dapat dikatakan ,bahwa media itu memiliki tujuan-tujuan politik atau ideoligi tertentu. Jika sebuah media lebih mengutamakan peristiwa-peristiwa yang menonjol (kontroversi) sebagai komoditas berita tanpa pembelaan ideologis terhadap kekuatan politik, berarti media itu lebih berorientasii pada kepentingan pasar dan keuntungan secara ekonomis.

\footnotetext{
${ }^{6}$ Eriyanto,Analisi Framing,Cetakan V....,127.
}

7 Bill Kovach dan Tom Rosenstiel ....,75. 
Jika media lebih mengutamakan kejelasan peristiwa-perstiwa politik tanpa pretense ideologis dan ekonomis mungkin ia benar-benar ingin bersikap idealis untuk kepentingan setiap golongan.

Penggunaan bahasa memiliki peran yang sangat penting dalam mendukung ideologi media. Karena dengan bahasa orang akan paham terhadap berita yang disampaikan. Mansour Fakih berbicara, asumsi bahwa bahasa adalah media komunikasi yang berwatak netral tentu akan membawa dampak terhadap tumbuhnya sikap, bahwa bahasa adalah area yang damai dan harmoni, sehingga bahasa tidak perlu digugat maupun dicurigai. Apalagi kemudian digali untuk dilihat kemungkinan tersembunyi dalam bahasa, yang akan mengakibatkan bencana ketidakadilan sosial dan bencana lain yang akan merendahkan martabat kemanusian. Namun sebaliknya, bagi kaum tertindas bahasa juga menjadi media pembebasan. ${ }^{8}$

Secara umum dapat dikatakan bahawa bahasa media merupakan cerminan atau rekonstruksi realitas. Oleh karena itu, bahasa pers mau tidak mau mempunyai kaitan dengan realitas sosial dan politik. Pan dan Kosieki menegaskan bahwa media sangat sensitif terhadap pemakaian bahasa tertentu, dimana seorang politisi menggunakan sejumlah langkah dan strategi tertentu dalam mengemas suatu pesan. Menurut mereka, pilihan kata-kata tertentu yang dipakai dan akhirnya diliput oleh media tidaklah dipahami sebagai pilihan yang netral, karena kata-kata itu sudah dikemas sedemikian rupa untuk mendapatkan dukungan publik. ${ }^{9}$

\section{Media Online Bangsaonline.com dan Potretjember.com Memberitakan Kontroversi JFC ke-18 Tahun 2019}

Pada bagian ini peneliti akan menguraikan bagaimana Bangsaonline.com dan Potretjember.com dalam memberitakan kontroversi JFC ke-18 tahun 2019.

a. Pemberitaan Kontroversi JFC ke-18 Tahun 2019 di Bangsaonline.com.

Dari pemetaan dengan menggunakan analisis framing terhadap beberapa berita tentang kontroversi JFC ke-18 tahun 2019 seperti yang sudah di paparkan pada bab sebelumnya, konstruksi berita yang diberitakan oleh media online Bangsaonline.com bisa dilihat dari tabel di bawah ini :

\footnotetext{
${ }^{8}$ Arwan Tuti Artha, Bahasa Dalam Wacana Demokrasi dan Pers (Yogyakarta: AK Group, 2002), xiii.

${ }^{9}$ Eriyanto,Analisi Framing,Cetakan V...., 252.
} 


\begin{tabular}{|c|c|}
\hline \multicolumn{2}{|r|}{ Struktur Frame Berita Bangsaonline.com } \\
\hline \multicolumn{2}{|c|}{ Framing Devices } \\
\hline Metaphors & $\begin{array}{l}\text { Kontroversi Tampilan Cinta Laura dalam balutan busana } \\
\text { Hudog, dimana hudog diartikan sebagai tikus, singa, gagak } \\
\text { dan lain-lain. }\end{array}$ \\
\hline Cactphrases & Dinilai pamer aurat, MUI kecam busana Cinta Laura di JFC \\
\hline Exemplars & $\begin{array}{l}\text { Tampilan seksi dengan balutan busana hudog yang } \\
\text { dikenakan Cinta Laura meriahkan JFC dan memuai } \\
\text { kontroversi }\end{array}$ \\
\hline Deptictions & ASJ tuntut Bupati dan pihak JFC meminta maaf \\
\hline Visual images & Kecam busana Cinta Laura di JFC \\
\hline \multicolumn{2}{|c|}{ Reasoning Devices } \\
\hline Roots & Cinta Laura yang mengenakan busana seksi \\
\hline $\begin{array}{l}\text { Appeals } \\
\text { Principle }\end{array}$ & $\begin{array}{l}\text { Pengurus Muhammadiyah angkat suara tentang pro dan } \\
\text { kontra terhadap JFC }\end{array}$ \\
\hline Concequences & Terjadinya aksi demo oleh ASJ \\
\hline
\end{tabular}

Framing Devices (Perangkat Pembingkai). Untuk mendukung

bingkai inti yang telah dipaparkan sebelumnya, Bangsaonline.com menggunakan perangkat-perangkat seperti methapors, catchphrases, exemplars, depictions, dan visual images.

Metaphors. Bangsaonline.com menggunakan metafora "seperti kontroversi" untuk menggambarkan perdebatan yang muncul. Karena itu istilah "kontroversi atau dan polemik" paling mendominasi dalam pemberitaan kontroversi JFC ke 18 tahun 2019 yang dikemas Bangsaonline.com. Istilah kontroversi atau polemik digunakan Bangsaonline.com untuk menggambarkan ketidaksetujuan masyarakat terhadap busana yang dikenakan oleh Cinta Laura. Dimana pada saat itu Cinta menggunakan busana Hudog. Arti Hudog itu sendiri adalah sejenis festival yang berupa tarian ungkapan syukur yang digelar oleh sub-etnis Dayak di Provinsi Kalimantan Timur. Namun yang menjadi kontroversi atau polemik ialah busana hudog yang menyalai nilai-nilai keagamaan, sebagaimana yang tertera di bawah ini: 
Pertemuan yang diinisiasi Majelis Ulama Indonesia (MUI) Jember membahas polemik gelaran Grand Carnaval Jember Fashion Carnival (JFC) ke-18. Diketahui dalam pertemuan tersebut, membahas dan menyikapi suasana, serta perasaan para kiai di Jember. 10

Selain polemik dalam pemberitaan Bangsaonline.com, kontroversi JFC yang terjadi. Bangsaonline.com berusaha mengingatkan kembali kepada khalayak bahwa busana yang dipakai oleh Cinta sangat bertentangan dengan citra Jember, dimana Jember disebut sebagai kota santri dan kurang mengangkat kearifan lokal.

Senada dengan yang disampaikan Ketua MUI Jember Prof. Abdul Halim Subahar, Ketua PD Muhammadiyah Jember Kusno, menyayangkan tampilan JFC yang dinilai kurang mengangkat kearifan lokal, dan juga kurang menghargai nilai-nilai dari kota santri. ${ }^{11}$

Kata "kurang menghargai nilai-nilai dari kota santri" dalam kalimat diatas, mengartikan bahwa kontroversi telah terjadi karena tampilan Cinta kurang menghargai nilai-nilai dari kota santri.

Apa yang dilakukan oleh Bangsaonline.com ini sebagaimana yang dikatakan Masnur Muslich bahwa berita ibarat sebuah drama. Ia tidak menggambarkan realitas, tetapi potret dari arena atau panggung pertarungan dari berbagai pihak yang berkaitan dengan peristiwa. Berita juga dibumbui dengan analisis dari berbagai pihak dan tokoh yang terlibat. Semua itu dikemas dalam berita bagaikan drama yang dipertontonkan kepada khalayak. Artinya pembaca disuguhi adegan berdasarkan frame media. $^{12}$

Catchphrases. Perangkat ini merupakan istilah, bentukan kata, atau frase khas cerminan fakta merujuk pada pemikiran atau semangat sosial tertentu guna mendukung praktik kekuasaan. Bangsaonline.com menggunakan judul "Dinilai Hanya Pamer Aurat, MUI Kecam Busana Cinta Laura di Jember Fashion Carnival" ketika terjadi sebuah polemik.

\footnotetext{
10 Bangsaonline.com, "Bahas Polemik Karnaval, MUI JemberInisiai Pertemuan dengan Manajemen JFC".06 Agustus 2019

11 Bangsaonline.com. muhammadiyah-jember-soal-pro-kontra-jfc-jangan-luruhkan-nilai-kota-santri-danpancasila. 05 Agustus 2019

12 Masnur Muslich. Kekuasaan Media Massa. Dalam Jurnal Bahasa dan Seni tahun 36 Nomor 2 Agustus
} 
Namun demikian, setelah perhelatan JFC berakhir, beragam komentar muncul di sejumlah sosial media (sosmed). Mayoritas mencibir penampilan Cinta yang dinilai terlalu vulgar dan berani, saat berada di Jember, yang notabene mendapat sebutan sebagai Kota Santri ini.

Judul yang bisa disebut juga sebagai frase ini sekaligus bisa digunakan untuk mempertegas terjadinya kontroversi. Hal ini tampak ketika Bangsaonline.com menuliskan berita bahwa banyaknya cibiran dari khalayak tentang penampilan Cinta yang dinilai terlalu vulgar dan berani.

Pemberitaan Bangsaonline.com yang menambahkan kritikan pedas dari Gus Halim semakin menonjolkan terjadi ketidaksinambungan terhadap pagelaran ini. Kritikan yang dilontarkan oleh Gus Halim ini terkait JFC pada tahun ini dianggap gagal dalam mendesain kostum untuk Cinta. Sehingga kostum yang dikenakan oleh Cinta ini tidak pantas dipertontonkan di ruang publik.

Event itu kan setiap tahun ada, harusnya panitia bisa lebih selektif. Intinya tidak selayaknya suguan atas nama kreatif seni Budaya justru meluruhkan dan menafikkan kesejatian nilai budaya bangsa yang agamis, berkeperimanusian yang berkeadaban dan berkeadilan,"ujar Kusno saat dikonfirmasi wartawan melalui telepon selulernya.

Selain kritikan dari Gus Halim, kritikan juga datang dari bapak Kusno. Beliau menilai bahwa pagelaran JFC ini tidak selayaknya menjadi suguan seni budaya justru meluruhkan dan menafikkan kesejatian nilai budaya yang agamis. Dari dimunculkannya kritikan yang dilontarkan oleh bapak Kusno, menjadi hal yang memperkuat, mempertegas adanya kontroversi atau polemik dalam pagelaran JFC ini, sehingga mempengaruhi cara pandang khalayak atau masyarakat.

Kendati demikian, sebagaimana sebuah pemberitaan, yang harus menyeimbangkan beritanya terkait kontroversi yang terjadi. Bangsaonline.com juga melakukan hal yang sama, yakni menghadirkan komentar dari pihak manajemen JFC.

Exemplars. Perangkat ini menguraikan atau mengemas fakta tertentu secara mendalam agar memiliki bobot makna lebih pada satu sisi untuk dijadikan rujukan atau pembelajaran. 
Bansaonline.com menuliskan sejarah dalam pengkritikan busana Cinta, yang dinilai belum memenuhi nilai-nilai keagamaan. Fakta sejarah inilah yang digunakan Bangsaonline.com untuk mengkritik pihak manajemen JFC terhadap busana yang dikenakan Cinta yang dipakai dalam pagelaran JFC ke 18 tahun 2019. Adanya sejarah yang tertulis menjelaskan makna dari busana hudog itu sendiri.

Dilansir dari wikipedia, Hudoq adalah sejenis festival yang berupa tarian ungkapan syukur yang digelar oleh sub-etnis Dayak di Provinsi Kalimantan Timur. Hudoq adalah kesenian tarian yang menggunakan topeng dan kostum, serta termasuk golongan kesenian barongan.

Menurut kepercayaan tradisional orang Bahau, Busang, Modang, Ao'heng dan Penihing, Hudoq adalah 13 hama yang merusak tanaman seperti tikus, singa, gagak, dan lain-lain. Dalam festival tersebut Hudoq dilambangkan oleh penari yang mengenakan topeng yang mewakili hama dan rompi yang terbuat dari pinang atau kulit kayu pohon pisang.

Menurut tradisi, festival hudoq diadakan setiap selesai menugal (menanam padi) di ladang September-Oktober setiap tahun. Maknanya, memohon berkat Tuhan agar padi yang ditanam nanti menghasilkan bulir yang berlipat-lipat hingga membawa kemakmuran bagi masyarakat. Secara turun-temurun, festival itu digelar berpindah-pindah dari desa ke desa lain setiap tahun.

Penjelasan busana hudog, menjelaskan tentang kepercayaan tradisional orang bahau, Busang, Modang, Ao'heng dan Penihing. Festifal hudog dimaknai untuk memohon berkat Tuhan agar padi yang ditanam nantinya menghasilkan bulir yang berlipat hingga membawa kemakmuran bagi masyarakat. Dalam hal ini untuk memohon berkat dari Tuhan, yang seharusnya dilakukan dengan cara yang baik dan sopan, dan menggunakan balutan busana yang seharusnya tidak memperlihatkan lekuk tubuhnya. Akan tetapi dalam pagelaran JFC, Cinta menggunakan busana Hudog yang memperlihatkan lekuk tubuhnya. Artinya Cinta yang mengenakan busana yang dirancang oleh pihak JFC ini, bertolak belakang dengan makna sejarah dari busana Hudog. 
Selain sejarah busana hudog, sejarah yang berlatarkan pesantren juga dihadirkan dalam pemberitaan Bangsaonline.com.

Event JFC dengan mengumbar aurat telah melukai hati para pejuang Jember yang berlatar belakang Pesantren seperti KH. Ahmad Shidig, KH. Khotib Umar dan segenap tokoh yang telah berjuang dengan susah payah mencitrakan Jember sebagai kota religious," ujar salah satu perwakilan aksi asal Tanggul, Akhmad Taufik saat dikonfirmasi sejumlah wartawan di sela aksi.

Bangsaonline.com menegaskan kembali, bahwa fakta Jember yang menyandang predikat kota religious ini dimana predikat tersebut didapat dengan susah payah oleh para tokoh-tokoh agama, namun pada kenyataan pada pagelaran JFC justru menampilkan penampilan yang bertolak belakang dengan predikat Jember sebagai kota yang religious.

Depictions. Perangkat ini merupakan penggambaran fakta memakai kata, istilah, kalimat bermakna konotatif, dan bertendensi khusus agar pemahaman khalayak terarah kecitra tertentu.

Bangsaonline.com menggunakan fakta berupa judul "Tuntut Bupati dan JFC Minta Maaf, ASJ Demo Pemkab Jember". Judul tersebut menggambarkan suasana penonton yang kurang meyukai tampilan Cinta dalam pagelaran JFC ke-18 tahun 2019. Dan dalam pemberitaannya puluhan santri melakukan unjuk rasa di depan kantor Kabupaten Jember.

Puluhan santri yang mengatasnamakan dirinya Aliansi Santri Jember (ASJ) melakukan aksi unjuk rasa di depan Kantor Pemkab Jalan Sudarman, Kecamatan Patrang, Kabupaten Jember, Jawa Timur, Rabu (7/8/2019).

Gambaran puluhan santri yang sedang melakukan aksi unjuk rasa ini menciptakan stigmatisasi dan pencitraan tertentu terhadap pagelaran JFC. Keadaan ini seolah mengesankan apa yang dilakukan oleh pihak manajemen JFC sangat menyalai aturan dari nilai-nilai keagamaan. Sehingga pihak-pihak yang dianggap pendukung dalam acara ini, dituntun untuk meminta maaf kepada khalayak atau masyarakat karena sudah dianggap melukai hati para pejuang Jember yang berjuang untuk mendapatkan citra Jember sebagai kota religious. 
Visual Images. Untuk mendukung bingkai inti. Bangsaonline.com menampilkan gambar Cinta yang sedang mengenakan busana hudog sehingga terjadi kontroversi atau polemik.

b. Pemberitaan Kontroversi JFC ke-18 Tahun 2019 di Potretjember.com.

Dari pemetaan dengan menggunakan analisis framing terhadap beberapa berita tentang kontroversi JFC ke-18 tahun 2019 seperti yang sudah di paparkan pada bab sebelumnya, konstruksi berita yang diberitakan oleh media online Potretjember.com bisa dilihat dari tabel di bawah ini :

\begin{tabular}{|l|l|}
\hline \multicolumn{2}{|c|}{ Struktur Frame Berita Potretjember.com } \\
\hline Framing Devices & Umbar aurat yang dilakukan oleh Cinta Laura \\
\hline Metaphors & $\begin{array}{l}\text { Tidak perlu adanya aksi percayakan kepada Ulama } \\
\text { dan umbar aurat }\end{array}$ \\
\hline Cactphrases & $\begin{array}{l}\text { Pagelaran JFC pada tahun 2019 lebih tidak menghargai } \\
\text { budaya lokal dan nilai keagaman }\end{array}$ \\
\hline Exemplars & $\begin{array}{l}\text { Bupati Jember dan manajemen JFC meminta maaf } \\
\text { kepada seluruh masyarakat Jember }\end{array}$ \\
\hline Depictions & Penggambaran busana Cinta \\
\hline Reasoning Devices & $\begin{array}{l}\text { Penggambaran ketika kontroversi terjadi } \\
\text { Roots }\end{array}$ \\
\hline Appeals Principle & Pro dang mentra dari pihak manajemen dan masyarakat \\
\hline Concequences & Terjadi aksi yang dilakukan ASJ di Pemkab Jember \\
\hline
\end{tabular}

Framing Devices (Perangkat Pembingkai). Sebagaimana dalam tabel kontroversi JFC ke-18 tahun 2019 dalam frame Potretjember.com peneliti akan menguraikan secara detail pembigkaian yang terdiri dari methapors, catchphrases, exemplars, depictions, dan visual images.

Methapors. Untuk menggambarkan kontroversi yang terjadi, Potretjember.com menggunakan metafora dengan kata "umbar aurat". Metafora ini dibangun dengan kalimat saling sentil antara tokoh agama dan pihak manajemen JFC. Menggunakan kata tersebut dimaknai dengan Cinta membuka auratnya di khalayak atau di masyarakat. Sehingga disebut sebut tidak menghargai budaya Jember yang terkenal dengan kota santri. 
Selain polemik dalam pemberitaan Potretjember.com, kontroversi JFC yang terjadi. Potretjember.com berusaha mengingatkan kembali kepada khalayak bahwa busana yang dipakai oleh Cinta sangat bertentangan dengan citra Jember, dimana Jember disebut sebagai kota santri dan kurang mengangkat kearifan lokal.

Catchphrases. Potretjember.com meneggunakan jargon "umbar aurat". Jargon ini seolah memberikan pembenaran kepada khalayak bahwa penampilan Cinta yang dilakukan dalam event JFC ke-18 tahun 2019. Dan jargon ini juga seolah ingin mengatakan pada masyarakat bahwa Cinta sudah tidak mengindahkan nilai-nilai agama atau aturan-aturan yang ada di Kabupaten Jember dalam event JFC. Kata-kata tersebut sekaligus mengkonstruk masyarakat bahwa pihak manajemen yang membuatkan busana Cinta. Akan tetapi masyarakat tidak mau tahu, yang mereka tahu bahwa Cinta sudah memakai busana yang memperlihatkan auratnya.

Sementara jargon "tak perlu aksi, pasrahkan saja pada ulama", disinggung Potretjember.com ketika Prof. KH. Halim Subahar memberikan komentarnya. Pernyataan Prof. Halim ini tampak tidak memiliki signifikansi. Potretjember.com mencitrakan bahwa polemik atau kontroversi ini sudah terjadi. Masyarakat dikonstruk untuk percaya pada ulama untuk menyelesaikan tentang kontroversi ini. Dengan menampilkan himbauan kepada masyarakat dan mempercayakan penyelesainnya kepada ulama.

Exemplars. Potretjember.com menggunakan rujukan sejarah Jember sebagai kota pesantren. Karena itu Potretjember.com menggunakan exemplars yang dikutip dari pernyataan aksi demo yang mengatakan bahwa Event JFC dengan mengumbar aurat telah melukai hati para pejuang Jember yang berlatar belakang Pesantren seperti KH. Ahmad Shidiq, KH. Khotib Umar dan segenap tokoh yang telah berjuang dengan susah payah mencitrakan Jember sebagai kota religius.

Pernyataan tersebut seolah ingin mengingatkan pada khalayak bahwa Jember yang pada saat ini menyandang sebutan Jember sebagai kota santri tentu tak lepas dari usaha para tokoh agama yang terdahulu. Yang sudah bersusah payah membangunnya. Potretjember.com bahkan terus memilih 
kata "melukai hati para pejuang" untuk membenarkan bahwa Jember ini masih mempunyai citra sebagai kota santri.

Potretjember.com menampilkan pernyataan salah stau peserta aksi yang menilai bahwa Cinta Laura dinilai tidak mencerminkan masyarakat Jember yang bertradisi pesantren. Dan terlebih lagi ketika Cinta menggunakan busana yang ditampilkan di depan publik, dimana banyak anak-anak dan tokoh yang hadir dipandang jauh dari nilai-nilai kesopanan.

Depictions. Untuk membangun core frame, Potretjember.com memberi label Bupati dan pihak manajemen memberikan pernyataan permintaan maaf kepada seluruh masyarakat khususnya masyarakat Jember. Hal ini diberitakan bahwa Bupati Jember dr. Faida MMR dengan didampingi Wakil Bupati Muqit Arief dan pihak Yayasan JFC menyampaikan permohonan maaf kepada suluruh masyarakat Indonesia khususnya masyarakat Jember, dan akan melakukan evaluasi pada kegiatan-kegiatan berikutnya. Pernyataan ini ditampilkan membuat polemik atau kontroversi ini terkesan telah selesai.

Visual Images. Potretjember.com menampilkan gambar Cinta ketika beraksi berjalan di runway menunjukkan busana yang dinilai mengumbar aurat.

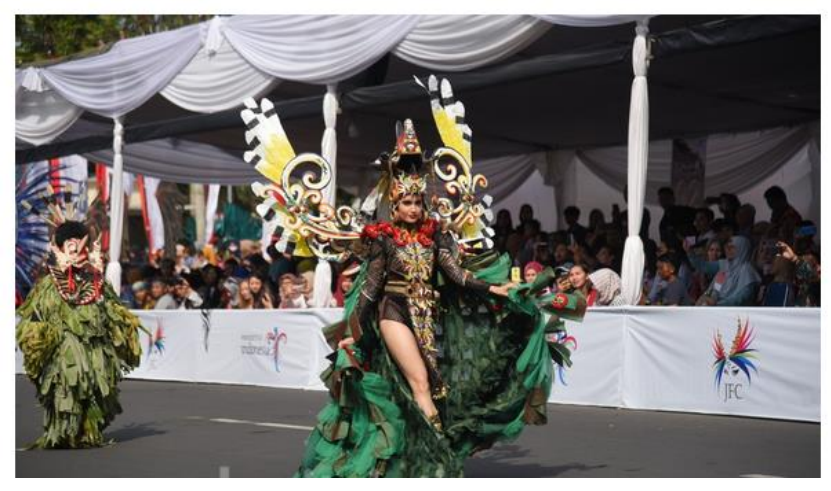

\section{Gambar 3}

Cinta Laura sedang beraksi di runway

Pada gambar di atas Cinta memakai busana Hudog dan berjalan menampilkan busana yang dipakainya. Digambar terlihat jelas, Cinta memperlihatkan kakinya yang jenjang dan mulus. Tampilan Cinta ini banyak menuai kritikan dan kontroversi yang dinilai tidak menunjukkan budaya kota Jember yang memiliki citra sebagai kota santri. 
Reasoning Devices (Perangkat Penalaran). Perangkat ini terbagi dalam tiga perangkat yaitu roots, appeals to principle dan consequences. Penggunaan ketiga perangkat ini akan menjawab perangkat penalaran.

Roots. Terjadinya kontroversi dipagelaran JFC ke-18 tahun 2019, disebabkan oleh Cinta Laura memakai busana Hudog yang dinilai mengumbar aurat. Kontroversi ini terjadi hingga mengundang organisasi agama untuk mengusulkan ditiadakan event ini. Selain itu ASJ juga mengadakan aksi di depan Pemkab Jember. Kontroversi ini dianggap selesai setelah MUI mengadakan pertemuan dengan tokoh-tokoh agama dan budayawan Jember untuk membahas polemik yag terjadi. Dan keputusannya Bupati Jember dan pihak manajemen meminta maaf kepada seluruh masyarakat khususnya masyarakat Jember atas keteledoran yang terjadi di event JFC ke-18 tahun 2019 ini. Berikut beberapa kutipan yang ditampilkan media online Potretjember.com :

"Perhelatan Jember Fashion Carnival (JFC) 2019 memang sudah berlalu, namun event yang pertama kalinya tanpa sang Pendiri JFC Dynand Fariz ini banyak menuai pro dan kontra ditengah masyarakat Jember, terutama dengan kostum yang dikenakan oleh artis Cinta Laura dan juga Putri Indonesia Frederika Alexis Cull."

"Puluhan santri yang tergabung dalam Aliansi Santri Jember (ASJ) tetap melakukan aksi demo di depan halaman Pemerintah Kabupaten Jember meski Forkopimda, Tokoh Agama dan Ulama sudah menggelar pertemuan pada Selasa sore (6/8/2019) untuk menyikapi event Jember Fashion Carnival (JFC) ke 18 yang terkesan mengumbar aurat."

"Semuanya sudah mengevaluasi terhadap apa yang terjadi dan menyesalkan keteledoran yang terjadi kemarin dalam event JFC," ujar Ketua PCNU Jember KH. Abdullah Syamsul Arifin atau yang akrab disapa Gus Aab usai melakukan pertemuan di Pendopo Wahyawibawagraha Jember."

"Polemik pada event Jember Fashion Carnival (JFC) 2019 terkait 'umbar aurat' yang menuai pro kontra ditengah masyarakat, Bupati Jember dr. Faida MMR dengan didampingi Wakil Bupati Muqit Arief dan pihak Yayasan JFC menyampaikan permohonan maaf kepada suluruh masyarakat Indonesia khususnya masyarakat Jember, dan akan melakukan evaluasi pada kegiatan-kegiatan berikutnya."

Appeals To Principle. Meski Potrerjember.com tidak terang-terangan mengklaim salah satu dari pihak manajemen atau tokoh agama terutama 
terkait koontroversi JFC yang mengarah pada masalah moral, namun terlihat jelas Potrerjember menggambarkan kontroversi yang terjadi.

"Suyanto menilai, bahwa insiden pro kontra pada kostum yang dikenakan beberapa talent pada pagelaran JFC ke-18 kemarin, oleh kakak kandung Dynand Fariz ini diibaratkan kebocoran. "Kita anggap sebuah kebocoran, dan tentunya kita tambal, dan soal aurat yang tadi di persoalkan, tahun depan akan kami perhatikan betul karena aurat itu mulai dari ujung rambut sampai ujung kaki, dan ini akan menjadi perhatian kami," pungkasnya."

Kalimat "kita anggap sebuah kebocoran" yang diungkapkan oleh pihak JFC mencerminkan sikap tanggap yang diambil oleh para ulama terhadap aksi ASJ yang penyebabnya ialah tentanga busana yang dipakai dalam event JFC.

Consequences. Dari pembingkaian yang dibangun Potretjember.com, Cinta Laura dianggap tidak mengindahkan nilai-nilai keagamaan dan diangap tidak menampilkan budaya Jember yang menyandang citra Jember sebagai kota santri. Sehingga Potretjember.com mencitrakan bahwa pagelaran JFC ke-18 tahun 2019 sudah menimbulkan kontroversi atau polemik. Kontroversi digambarkan dari tampilan Cinta yang mengenakan busana Hudog yang dinilai berbanding terbalik dengan penyandangan kota Jember sebagai kota santri.

\section{Metodologi}

Pendekatan yang dipakai pada penelitian ini ialah pendekatan secara kualitatif deskriptif. Hal ini didasarkan pada data informasi yang dikaji dalam bentuk dokumentasi teks berita dalam media online.Data ini selanjutnya akan direkonstruksi dan diinterpretasikan untuk menghasilkan sebuah gambaran konstruksi realitas tentang subjek penelitian. Karakteristik penelitian kualitatif menurut pendapat Creswell adalah meneliti lingkungan alamiah, peneliti sebagai instrument kunci, beragam sumber data (wawancara, observasi, dokumentasi), analisis data induktif, makna dari partisipan, rancangan yang berkembang, perspektif teoritis, bersifat penafsiran, pandangan menyeluruh.13 Pendekatan kualitatif dipandang relevan oleh peneliti karena konsep yang dikaji adalah perspektif media dalam membingkai pesan tentang konstruksi media terhadap kontroversi JFC 2019. Prinsip penelitian kualitatif adalah mengamati sesuatu fakta

13 John W. Creswell, Research design, (Yogyakarta: Pustaka Pelajar, 2010),261-263) 
untuk mengetahui faktor-faktor apa saja yang berada di balik fakta tersebut serta untuk melihat kecenderungan-kecenderungannya. Fakta dalam penelitian ini adalah berita seputar kontroversi JFC 2019 dalam media online bangsaonline.com dan potretjember.com.

Penelitian ini dilakukan di media online Bangsaonline.com dan Potretjember.com. Media online ini dipilih karena kedua media ini merupakan media Jawa Timur dan juga media yang paling banyak memuat tentang kontroversi JFC ke18 tahun 2019. Perbedaan karakteristik kedua media online juga menjadi pertimbangan peneliti untuk memilih kedua media online ini. Maka dari pertimbangan tersebut, peneliti memilih media online Bangsaonline.com dan Potretjember.com sebagai lokasi penelitian. Untuk mendukung data yang akan diperlukan maka dalam penelitian ini pencarian data dilakukan dengan cara menghimpun semua data teks pemberitaan kontroversi JFC 2019 di media online bangsaonline.com dan potretjember.com pada saat dimulainya acara JFC yang ke-18 sampai dengan terjadi kontroversi JFC sampai khalayak menyampaikan aspirasinya. Selain itu data juga didapat dari tokoh agama di Jember sebagai informan sebagai pelengkap data, yakni Ketua MUI Jember, Pengurus Muhammadiyah Jember dan Ketua FPI Jember.

Temuan dan Diskusi (Font Cambria 12 pt Bold)

Dari hasil dan pembahasan yang telah diuraikan pada bab sebelumnya menunjukkan bahwa Bangsaonline.com dan Potretjember.com dalam mengemas peristiwa kontroversi JFC ke-18 tahun 2019, sama akan tetapi berbeda cara memberitakannya sesuai dengan ideologi yang mendasarinya. Pada media dalam mempersepsi sebuah peristiwa sebagaimana Bangsaonline.com dan Potretjember.com dalam memberitakan kontroversi JFC dapat dibahas sebagai berikut:

Media online Bangsaonline.com lebih menonjolkan kesalahan dari pihak manajemen JFC atau pihak-pihak yang berkaitan. Dalam penulisan judul berita di Bangsaonline.com tampak memosisikan secara seimbang antara pihak manajemen dengan tokoh-tokoh agama atau dengan orang-orang yang tidak setuju dengan tampilan pada even JFC ke-18 tahun 2019 ini. Seperti judul “Tampilan Seksi dengan Balutan Busana Hudog, Cinta Laura Meriahkan JFC". 
Penulisan judul berita ini sama sekali tidak mengesankan bahwa Bangsaonline.com berpihak pada kedua belah pihak. Namun dalam pengemasan beritanya, kata, istilah, frasa, kalimat, fakta, paragraph, maupun gambar digunakan media online ini cenderung menonjolkan citra Cinta yang mengumbar aurat dan menyalahai nilai-nilai keagamaan. Pemilihan gambar Cinta yang tidak menutupi paha misalnya, menunjukkan bahwa Bangsaonline.com cenderung terhadap pihak tertentu.

Sedangkan media online Potretjember.com dalam memberitakan kontroversi JFC ke-18 tahun 2019 tidak jauh berbeda dengan Bangsaonline.com. Potretjember.com tampak malu-malu ketika memberitakan kontroversi yang terjadi. Bahkan setiap judul berita event JFC memperlihatkan bahwa Potretjember.com memiliki kecenderungan untuk menonjolkan sisi positif dari pihak manajemen dari pada kontroversi yang terjadi dalam event JFC ke-18 tahun 2019. Tetapi tetap memperlihatkan kontroversi atau polemik yang terjadi. Contohnya saja dalam judul “Tak Perlu Ada Aksi, Percayakan Pada Ulama”. Penilaian dari judul yang tertera, mengesankan bahwa Potretjember.com sama sekali tidak berpihak pada kedua belah pihak. Namun dalam pengemasan beritanya, kata, istilah, frasa, kalimat, fakta, paragraph, maupun gambar digunakan media online ini cenderung menonjolkan citra tokoh agama yang sigap dan tanggap dalam pemberitaan kontroversi JFC yang terjadi.

Dengan menggunakan analisis framing model Gamson dan Modigliani yang didasarkan pada teori konstruk sosial (social construction) Peter L. Beger dan Thomas Luckman, maka hasil penelitian ini menunjukkan bahwa media online dalam hal ini Bangsaonline.com dan Porterjember.com menyajikan realitas dengan kosntruksi tertentu dan berbeda kepada khalayak.

Menurut Berger dan Luckman, realitas itu tidak dibentuk secara ilmiah. Tetapi sebaliknya, ia dibentuk dan dikonstruksi. Proses konstruksi realitas dimulai ketika seseorang melakukan objektivikasi terhadap suatu kenyataan yakni melakukan persepsi terhadap suatu objek. Selanjutnya, hasil pemaknaan proses persepsi itu diinternalisasikan ke dalam diri orang tersebut. Dalam tahap inilah dilakukan konseptualisasi terhadap suatu objek yang dipersepsi. Langkah selanjutnya adalah melakukan eksternalisasi atas hasil dari proses permenungan 
secara internal tadi melalui pernyataan-pernyataan. Sebagai alat pembuat pernyataan tersebut adalah kata-kata atau bahasa. ${ }^{14}$

Dari realitas yang tercermin dari dua media online tersebut, menunjukkan bahwa sistem pers yang perlaku di Indonesia memberikan kebebasan pada media untuk mengemas peristiwa apa saja sebagaimana ideologi media. Keberanian Bangsaonline.com dan Potretjember.com untuk menonjolkan cara pemberitaan masing-masing media adalah salah satu imbas dari pemberlakuan sistem pers Indonesia.

Hasil wawancara dalam pandangan tokoh agama di Jember dalam menyikapi kontroversi JFC ke-18 tahun 2019 menurut pandangan Prof. Dr. H. Abd. Halim Soebahar, M.A. sebagai Ketua MUI Jember berpendapat bahwa dalam event ini kontroversi terjadi karena melanggar norma-norma agama dan norma atau nilai kemasyarakatan. Pelanggaran terhadap norma agama dan norma atau nilai kemasyarakatan itu sudah jelas. Misalkan, dengan mengundang Cinta Laura yang itu sangat mengumbar aurat. Dengan memperlihatkan bokongnya (pantat) saja kelihatan. Hanya ada sempaknya (celana dalam). Artinya secara agama sudah menyalai norma-norma yang berlaku dalam masyarakat. Sedangkan dari segi budaya, budaya juga mempunyai norma yang berlaku dalam kehidupan masyarakat, karena masyarakat mempunyai norma. Budaya tidak boleh melanggar norma yang dianggap penting dalam kehidupan masyarakat. Jadi yang namanya seni itu tidak bebas nilai. Yang dikatakan bebas nilai itu dilingkungan internal dan privasi. Seandainya itu melanggar norma masyarakat, maka harus koordinasi dengan masyarakat. Karna masyarakat tentu punya norma.

Mengenai pandangan dalam menyikapi kontroversi JFC ke-18 tahun 2019 menurut bapak Kusno selaku pengurus Muhammadiyah Jember perpandangan bahwa jika berbicara tentang JFC itu merupakan kreasi budaya yang sebenarnya secara umum karena kita manusia event JFC ini dianggap wajar. Tetapi dalam kehidupan seperti bangsa yang mempunya adab dan nilai-nilai luhur didalamnya. Nilai-nilai lihur disini ada ideologi pancasila, ada Bhineka tunggal ika ada ajaran agama. Harusnya didalam menyelenggarakan event, apalagi kegiatan itu yang melibatkan banyak orang dalam waktu yang relatif singkat.

14 Peter L. Berger dan Thomas Luckman.The Social Construction of Reality: A Treatise in the Sociology of Knowledge(London:Penguin Books,1991).384 
Misalkan JFC, yang pertama harusnya mengindahkan terhadap ketentuanketentuan agama yang berlaku di tengah masyarakat. Misalkan seorang muslim maka akan mengikuti ketentuan-ketentuan yang ada dalam ajaran islam. Dengan tidak boleh sebuah event itu di dalamnya ada Tabarujuj jahiliyah. Bersolek Memamerkan sesuatu yang orang jahiliyah dahulu melakukannya. Diantara Tabarujuj jahiliyah itu menampilkan lekuk indah nya tutup yang digerak-gerakkan. termasuk tabarun jahiliyah itu pakaian yang tidak standar tidak mampu untuk menutup aurat dan tidak pula memberikan rasa aman dan nyaman bagi yang menggunakan maupun bagi yang menyakitkan dan yang melibatkan.

Sehingga fungsi pakaian yang sebenarnya itu menjadi keindahan dan kemuliaan martabat manusia yang memakai itu, itu tidak terwujud. Maka dalam kegiatan yang demikian tidak selayaknya dipampangkan atau diselenggarakan apa lagi penyelenggaranya adalah Pemerintah daerah yang notabennya menjaga moral, menjaga keadapan di dalam kehidupan bermasyarakat. Itu dari segi Fashion atau entertaimennya.

Dari sisi waktu, JFC perlu untuk dirubah sedemikian rupa agar rentang waktu event ini menyalai waktu-waktu umat muslim menjalankan ibadahnya. Jadi kalau memang mau dilakukan setelah dhuhur berarti peserta sudah bisa melaksanakan salat zuhur dulu kemudian baru ditutup ketika waktu Ashar masih tersedia untuk dikerjakan oleh masing-masing orang itu. Karena yang kita lihat bahwa ketika waktu-waktu tersebut terlampaui begitu saja. walaupun ada sebagian waktu solat itu bisa untuk dijamak qosor ataupun di jamak. Akan tetapi ketentuan tersebut bisa dilakukan ketika dalam keadaan kesulitan ada musibah ada sesuatu yang memberatkan sehingga waktu solat itu dilakukan antara dhuhur dengan ashar. Perlu adanya komunikasi, berdiskusi dan berbagi bersama ahlinya. Dalam hal ini ahlinya Majelis Ulama Indonesia Kabupaten Jember, yang punya otoritas untuk memberi tausiyah atau saran masukan terkait dengan itu.

Sedangkan menurut Habib Haidar berpandangan bahwa jika berbicara event JFC berarti berbicara tentang seni budaya. Beliu berpendapat bahwa JFC belum seni budaya Indonesia tetapi budaya barat. Kenapa, karena masih banyak seni budaya Indonesia. Baginya dari sisi seni budaya. Dari sisi agama, dikatakan mereka mengumbar aurat, meninggalkan solat kebanyakan. Wanita-wanita diumbar dijalan dengan pakaian yang tidak senonoh dan bukan pakaian masyarakat Jember yang 
citranya sebagai kota santri. Jadi JFC ini bukan seni budaya Indonesia. Tidak mewakili budaya Indonesia. Sedangkan dari segi perekonomian menurutnya apakah tidak ada kreasi lain misalkan, dengan cara mengelolah alam, Jember yang begitu indah.

Media online Bangsaonline.com lebih menonjolkan kesalahan dari pihak manajemen JFC atau pihak-pihak yang berkaitan. Dalam penulisan judul berita di Bangsaonline.com tampak memosisikan secara seimbang antara pihak manajemen dengan tokoh-tokoh agama atau dengan orang-orang yang tidak setuju dengan tampilan pada even JFC ke-18 tahun 2019 ini.

Sedangkan media online Potretjember.com dalam memberitakan kontroversi JFC ke-18 tahun 2019 tidak jauh berbeda dengan Bangsaonline.com. Potretjember.com tampak malu-malu ketika memberitakan kontroversi yang terjadi. Bahkan setiap judul berita event JFC memperlihatkan bahwa Potretjember.com memiliki kecenderungan untuk menonjolkan sisi positif dari pihak manajemen dari pada kontroversi yang terjadi dalam event JFC ke-18 tahun 2019. Tetapi tetap memperlihatkan kontroversi atau polemik yang terjadi.

Bagi ketiga tokoh agama, ketua MUI Jember, Pengurus Muhammadiyah Jember dan Ketua FPI ranting Jember, konrtoversi JFC ke-18 tahun 2019 ini terjadi karena menyalahi nilai-nilai keagamaan dan norma-norma budaya yang ada dan berlaku di masyarakat Jember. Dimana Jember yang notabennya adalah kota santri. Berkomunikasi, berdiskusi dengan para ahli yang disini ahli agama dan ahli budaya adalah jalan yang harus dipilih oleh pihak manajemen JFC sehingga jika event JFC ini dihadirkan kembali tidak terjadi lagi kontroversi atau polemik kedepannya.

\section{KESIMPULAN DAN SARAN}

\section{Kesimpulan}

Media online Bangsaonline.com lebih menonjolkan kesalahan dari pihak manajemen JFC atau pihak-pihak yang berkaitan. Dalam penulisan judul berita di Bangsaonline.com tampak memosisikan secara seimbang antara pihak manajemen dengan tokoh-tokoh agama atau dengan orang-orang yang tidak setuju dengan tampilan pada even JFC ke-18 tahun 2019 ini. Sedangkan media online Potretjember.com dalam memberitakan kontroversi JFC ke-18 tahun 2019 tidak jauh berbeda dengan Bangsaonline.com. Potretjember.com tampak malu-malu 
ketika memberitakan kontroversi yang terjadi. Bahkan setiap judul berita event JFC memperlihatkan bahwa Potretjember.com memiliki kecenderungan untuk menonjolkan sisi positif dari pihak manajemen dari pada kontroversi yang terjadi dalam event JFC ke-18 tahun 2019. Tetapi tetap memperlihatkan kontroversi atau polemik yang terjadi.

Bagi ketiga tokoh agama yakni ketua MUI Jember, Pengurus Muhammadiyah Jember dan Ketua FPI ranting Jember, konrtoversi JFC ke-18 tahun 2019 ini terjadi karena menyalahi nilai-nilai keagamaan dan norma-norma budaya yang ada dan berlaku di masyarakat Jember. Dimana Jember yang notabennya adalah kota santri. Berkomunikasi, berdiskusi dengan para ahli yang disini ahli agama dan ahli budaya adalah jalan yang harus dipilih oleh pihak manajemen JFC sehingga jika event JFC ini dihadirkan kembali tidak terjadi lagi kontroversi atau polemik kedepannya.

\section{Saran}

Sebagai salah satu pilar demokrasi, pers atau media memiliki konstribusi yang cukup besar dalam membangun sebuah kebudayaan. Karena itu, sebagai sebuah saluran informasi, media diharapkan mampu menyalurkan pendapat masyarakat dengan tidak berpihak pada kelompok tertentu. Menurut peneliti hasil dari penelitian ini cukup membuktikan bahwa media tidak selamanya bebas dari kepentingan kelompok tertentu. Apapun yang dilakukan oleh media tidak selamanya sesuai dengan realitas sebenarnya, sebagaimana kontroversi ini terjadi.

Maka dari hasil penelitian ini, peneliti juga ingin merekomendasikan pada peneliti mendatang, hendaknya hasil dari frame media ini dilanjutkan dengan penelitian tentang frame individu (individual frame). Hal ini untuk mengetahui tingkat kesamaan antara frame media dengan frame individu (khalayak) sehingga dapat diketahui implikasi pemberitaan media dengan pemahaman individu (khalayak) dalam memandang sebuah peristiwa.

\section{DAFTAR PUSTAKA}

Creswell, John W. 2010. Research design.Yogyakarta: Pustaka Pelajar

Eriyanto, Analisis Framing (Konstruksi, Ideologi dan Politik Media,(Yogyakarta:PT.LKiS Printing Cemerlang.2002)

Peter L. Berger dan Thomas Luckman.The Social Construction of Reality: A Treatise in the Sociology of Knowledge (London:Penguin Books,1991) 
Masnur Muslich. Kekuasaan Media Massa. Dalam Jurnal Bahasa dan Seni tahun 36 Nomor 2 Agustus

Arwan Tuti Artha, Bahasa Dalam Wacana Demokrasi dan Pers (Yogyakarta: AK Group, 2002)

Bill Kovach dan Tom Rosenstiel, Sembilan Elemen Jurnalisme, Terjemahan, (Jakarta:Pantau,2003)

Stephen W. Littlejhon dan Karen A. Foss, Theoris of Human Communication. Ninth Edition.Belmont(California:Wadsworth Publishing Company,2008)

bangsaonline.com

potretjember.com 
Kontroversi JFC (Jember Fashion Carnaval) ke-18 Dalam Diskursus Media dan Pemikiran Tokoh Agama di Jember 